\title{
KONSISTENSI KONSTITUSI INDONESIA DALAM PELAKSANAAN JUDICIAL REVIEW UNDANG-UNDANG
}

\author{
Oleh: Jun Mawalidin \\ Universitas Islam Negeri Sunan Kalijaga Yogyakarta \\ e-mail: joenjun98@gmail.com
}

\begin{abstract}
The author in the observation of research studies on the constitusional court in Indonesia runs on the basis of government regulations and the 1945 constitution. The constitutional court, which was established since 2003, has proven its usefulnes and role in safeguarding the constitution and state ideology. All efforts and Ijtihad carried out by MK are solely for the sake of upholding social justice for all Indonesian people. The birth of the Indonesian constitution began during the independence period complied by the preparatory body for Indonesia's independence efforts (BPUPKI). The existence of the Constitutional Court in revising a law or other government regulation is a force for society to fight and seek justice for regulations. The Constitutional Court has reviewed the laws governing its authority dozens of times the Constitutional court's decision has left pros and cons. Judicial Review of laws in Indonesia can be carried out by the supreme court and the Constitutional court, however, the theory and laws are different.
\end{abstract}

Keywords: Constitutional Court, Constitution, MA, Government Regulations

\begin{abstract}
Abstrak
Penulis dalam pengamatan kajian penelitian tentang Mahkamah Konstitusi di Indonesia berjalan berdasarkan peraturan-peraturan pemerintah dan Undang-Undang Dasar 1945. Mahkamah Konstitusi yang terbentuk sejak 2003, telah membuktikan khidmah dan kiprahnya dalam menjaga konstitusi dan ideologi negara. Segala ikhtiar dan ijtihad yang dilakukan oleh MK adalah semata demi tegaknya keadilan sosial bagi seluruh rakyat Indonesia. Kelahiran konstitusi Indonesia diawali ketika masa kemerdekaan yang disusun oleh Badan Persiapan Usaha-usaha Kemerdekaan Indonesia (BPUPKI). Keberadaan MK dalam merevisi sebuah Undang-undang atau Peraturan Pemerintah lainya merupakan kekuatan bagi masyarakat dalam melawan dan mencari keadilan terhadap peraturan. Mahkamah Konstitusi sudah puluhan kali menguji undangundang yang megatur kewenanganya dan sudah puluhan kali pula putusan MK tersebut menimbulkan pro-kontra. Pengujian undang-undang di Indonesia di lakukan oleh MA dan MK namun secara teori dan dasarnya berbeda tugas.
\end{abstract}


Kata Kunci: Mahkamah Konstitusi, Konstitusi, MA, Peraturan Pemerintah

\section{A. Pendahuluan}

Pemikiran tentang konsep negara hukum telah lama dikembangkan oleh ahli filsafat dari zaman yunani kuno, seperti: Plato (429-374 SM). Pendapat dari Aristoteles memberikan pemahaman bahwa negara harus berdiri di atas hukum yang akan dapat menjamin keadilan bagi warga negara. Dengan menempatkan hukum sebagai hal yang tertinggi (supreme) dalam negara berarti, bahwa penyelenggaraan kekuasaan dalam negara khususnya kekuasaan pemerintahan haruslah didasarkan atas hukum. Dalam konsepsi negara hukum, kekuasaan menjalankan atau menyelenggarakan pemerintahan haruslah berdasarkan pada kedaulatan hukum atau supremasi hukum dengan tujuan utamanya ialah mewujudkan adanya ketertiban hukum dalam penyelenggaraan pemerintahan. ${ }^{1}$

Pada suatu negara di dunia pasti mempunyai konstitusi, karena konstitusi merupakan salah satu syarat penting untuk mendirikan dan membangun suatu negara yang merdeka, oleh karenanya begitu pentingnya konstitusi itu dalam suatu negara. Konstitusi merupakan suatu kerangka kehidupan politik yang sesungguhnya telah dibangun pertama kali peradaban dunia dimulai, karena hampir semua negara menghendaki kehidupan bernegara yang konstitusional, adapun ciri-ciri pemerintahan yang konstitusional diantaranya memperluas partisipasi politik, memberi kekuasaan legislatif pada rakyat, menolak pemerintahan otoriter dan sebagainya. ${ }^{2}$

Mahkamah Konstitusi yang terbentuk sejak 2003, telah membuktikan khidmah dan kiprahnya dalam menjaga konstitusi dan ideologi negara. Selama lebih dari 14 tahun Mahkamamah Konstitusi senantiasa berupaya meneguhkan peranya sebagai penjaga konstitusi dan ideologi serta sebagai pelindung hak konstitusional warga negara. Segala ikhtiar dan ijtihad yang dilakukan oleh MK adalah semata demi tegaknya keadilan sosial bagi seluruh rakyat Indonesia. Khidmah dan kiprah Mahkamah tersebut merupakan amanat Pasal 24C ayat (1) UUD 1945 yang menegaskan MK berwenang mengadili pada tingkat pertama dan terakhir yang putusanya bersifat final untuk menguji undang-undang terhadap Undang-undang Dasar 1945, memutus sengketa kewenanagan lembaga negara yang kewenanganya diberikan oleh Undangundang Dasar, memutus pembubaran partai politik, dan memutus perselisihan tentang hasil pemilihan umum. Sedangkan pada ayat (2) menyebutkan, Mahkamah wajib memberikan putusan atas pendapat Dewan Perwakilan Rakyat mengenai dugaan pelanggaran oleh Presiden dan/atau Wakil Presiden menurut Undang-undang Dasar. ${ }^{3}$

\footnotetext{
${ }^{1}$ Aminuddin Ilmar, Hukum Tata Pemerintahan, (Jakarta: Prenadamedia Group, 2014), hlm 48.

2 M. Agus Santoso, Perkembangan Konstitusi di Indonesia, (Yustisia Vol 2 No 3 2013).

${ }^{3}$ Mahkamah Konstitusi Republik Indonesia, Konsistensi Pada Konstitusi dan Ideologi Negara (Jakarta: Kepaniteraan dan Sekretariat Jenderal Mahkamah Konstitusi, 2018) hal, 5.
} 
Dalam menata negara yang besar membutuhkan banyak aturan-aturan sebagai dasar untuk ketertiban dan keamanan masyarakat seperti terbentuknya konstitusi. Asas legalitas dan asas konstitusional merupakan ciri yang harus dimiliki oleh sebuah negara hukum, sedangkan konstitusi atau UUD merupakan bentuk legalitas adanya peraturan secara tertulis. Dengan demikian secara konstitusional yang juga merupakan ciri pokok negara hukum telah terpenuhi, sehingga konstitusi atau UUD merupakan syarat mutlak yang harus dipenuhi dalam suatu negara hukum seperti Indonesia. Sedangkan bentuk konstitusi itu dalam suatu masa akan menggambarkan kondisi demokrasi pada masa itu pula. ${ }^{4}$

Salah satu tugas dan kewenangan yang diemban oleh Mahkamah Konstitusi Negara Republik Indonesia sebagai bagian dari pelaksana kekuasaan kehakiman, adalah melakukan Judicial Review, peninjauan dan atau pengujian kembali terhadap putusan badan legislasi dan atau eksekutif. ${ }^{5}$ kompetensi Mahkamah Konstitusi Indonesia di bidang Judicial Review ditujukan terhadap pengujian UU terhadap UUD baik dari segi formil maupun dari segi materi, yang biasa diistilahkan dengan pengujian konstitusionalisme. Dasar Mahkamah Konstitusi melakukan pengujian konstitusionalitas, ditemukan pada pasal 24C UUD NRI 1945 dan pula diatur lebih pada Pasal 10 UU No. 24 Tahun 2003 tentang Mahkamah Konstitusi dan perubahanya dengan UU. No. 8 Tahun $2011 .^{6}$

Doktrin pemisahan kekuasaan melahirkan prinsip "checks and balances", yang merupakan salah satu dasar lahirnya judicial review. Diujinya produk-produk hukum yang dibuat oleh legislatif dan eksekutif merupakan bentuk nyata dari dianutnya prinsip checks and balances. Penggunaan kewenangan hakim untuk melakukan pengujian terhadap produk hukum dinamakan judicial review, yakni apabila merujuk pada praktik di Indonesia adalah pengujian undangundangterhadap UUD 1945 yang dilakukan oleh Mahkamah Konstitusi (MK). Judicial Review adalah suatu mekanisme pengawasan norma melalui pengadilan, khususnya norma dalam sebuah undang-undang yang telah disahkan dan telah diundangkan secara resmi. ${ }^{7}$

Sejak berdiri pada 2003 hingga akhir 2017, MK telah melaksanakan tiga kewenanganya, yakni kewenangan melakukan pengujian undang-undang (PUU), sengketa kewenangan lembaga negara (SKLN), dan perselisihan hasil pemilihan umum (PHPU). sedangkan dua kewenangan lainya, hingga detik ini belum pernah dilakukan. Yakni kewenangan memutus pembubaran partai politik dan memberikan putusan dalam proses pemberhentian presiden/wakil presiden dalam

\footnotetext{
${ }^{4}$ M. Agus Santoso, Perkembangan Konstitusi di Indonesia, (Yustisia Vol 2 No 3 2013).

${ }_{5}^{5}$ Nurul Qomar, Kewenangan Judicial Review Mahkamah Konstitusi, (Jurnal Konstitusi, Vol 1 No 1 2012).

${ }^{6}$ Ibid.,

7 Jimly Asshiddiqie, Model-model Pengujian Konstitusional di Berbagai Negara, (Jakarta: Konstitusi Press, 2006) hal, 7.
} 
masa jabatanya. Kedua kewenangan ini belum pernah dilakukan karena memang belum pernah ada permohonan yang masuk ke MK terkait dua perkara ini. ${ }^{8}$

Dalam perkembanganya, berdasarkan Pasal 236C UU No. 12 Tahun 2008 Tentang perubahan kedua atas UU Nomor 32 Tahun 2004 tentang Pemda, MK juga diberikan amanah untuk mengadili perkara perselisihan Hasil Pemilihan kepala daerah (PHP Kada) yang sebelumnya merupakan kewenangan Mahkamah Agung (MA). Namun, pada mei 2014 MK mengeluarkan Putusan Nomor 97/PUU-XI/2013. Dalam putusan tersebut MK menegaskan bahwa pemilihan kepala daerah (Pilkada) bukan merupakan bagian dari rezim pemilu sehingga MK tidak memiliki wewenang untuk memeriksa dan memutusnya. Namun, karena belum terbentuknya lembaga yang akan menangani perkara perselisihan hasil pilkada, MK untuk sementara tetap menangani perkara tersebut. ${ }^{9}$

\section{B. Konstitusi di Indonesia}

Konstitusi ialah hukum dasar suatu negara dalam menyelenggarakan negara yang berasal dari kesepakatan atau perjanjian politik rakyat dengan penyelenggara negara. Memahami konstitusi berarti mengetahui mekanisme bagaimana kekuasaan negara ini dijalankan oleh badan-badan kekuasaan negara yang telah ditentukan dalam konstitusi. Oleh karena itu keberadaan suatu negara perlu ditunjang oleh hukum dasar yaitu konstitusi baik itu konstitusi yang tertulis atau tidak tertulis. Dua bentuk konstitusi yaitu tertulis dan tidak tertulis adalah bentuk umum yang dikenal saat ini atau juga dapat diartikan dua bentuk tersebut dalam konstitusi yang terdokumen dan tidak terdokumen. Arti bentuk terdokumen adalah bahwa aturanaturan dasar dalam penyelenggaraan negara terdapat dalam satu dokumen konstitusi seperti Undang-undang Dasar Negara Repubik Indonesia Tahun 1945. Sedangkan yang tidak terdokumen ini menunjukan bahwa aturan-aturan dasar dalam penyelenggaraan negara tersebut tidak menjadi satu dalam dokumen tertentu melainkan terdapat dalam berbagai aturan hukum atau konvensi atau kebiasaan yang telah disepakati untuk menjadi aturan dasar sebagai praktik ketatanegaraan. ${ }^{10}$

Kelahiran konstitusi Indonesia diawali ketika masa kemerdekaan yang disusun oleh Badan Persiapan Usaha-usaha Kemerdekaan Indonesia (BPUPKI). BPUPKI ini merupakan badan yang dibentuk oleh jepang dalam usaha mempersiapkan kemerdekaan Indonesia. Namun Indonesia baru resmi mempunyai konstitusi pada tanggal 18 Agustus 1945 yang disebut Undangundang Dasar Tahun 1945 dan disahkan oleh Panitia Persiapan Kemerdekaan Indonesia (PPKI).

\footnotetext{
${ }^{8}$ Mahkamah Konstitusi Republik Indonesia, Konsistensi Pada Konstitusi dan Ideologi Negara (Jakarta: Kepaniteraan dan Sekretariat Jenderal Mahkamah Konstitusi, 2018) hal, 5-6.

9 Ibid., hal 6.

10 Encik Muhammad Fauzan, Hukum Tata Negara Indonesia, (Malang: Setara Press, 2017) hal 44-45.
} 
Undang-undang Dasar Tahun 1945 inilah yang menjadi konstitusi pertama di Indonesia. Seiring perjalanan waktu dan perubahan ketatanegaraan Indonesia, Indonesia telah menrapkan beberapa konstitusi yaitu: ${ }^{11}$

1. Undang-undang Dasar Tahun 1945, yang disahkan oleh PPKI pada tanggal 18 Agustus 1945 dan berlaaku sampai 27 Desember 1949.

2. Konstitusi Republik Indonesia Serikat 1949, yang berlaku 27 Desember 1949 sampai 27 Agustus 1950

3. Undang-undang Dasar Sementara 1950, yang berlaku mulai 27 Agustus 1950 sampai 5 Juli 1959.

4. Undang-undang Dasar Tahun 1945, diberlakukan lagi melalui Dekrit Presiden 5 Juli 1959

5. Undang-undang Dasar Negara Republik Indonesia Tahun 1945, yang telh dilakukan perubahan oleh Majelis Permusyawaratan Rakyat (MPR) mulai tahun 1999 sampai dengan tahun 2002.

Dalam penyusunan suatu konstitusi tertulis, nilai-nilai dan norma dasar yang hidup dalam masyarakat dan dalam praktik penyelenggaraan negara turut mempengaruhi perumusan suatu norma ke dalam naskah Undang-undang Dasar. Oleh karena itu, suasana kebatinan (geistichenhentergrund) yang menjadi latar belakang filosofis, sosiologis, politis, dan historis perumusan juridis suatu ketentuan Undang-undang Dasar perlu dipahami dengan seksama, untuk dapat mengerti dengan sebaik-baiknya ketentuan yang terdapat dalam pasal-pasal Undangundang Dasar. Undang-undang Dasar tidak dapat dipahami hanya melalui teksnya saja. Untuk sungguh-sungguh mengerti, kita harus memahami konteks filosossfis, sosio-historis, sosiopolitik, sosio-juridis, dan bahkan sosio-ekonomis yang mempengaruhi perumusanya. ${ }^{12}$

Di samping itu, setiap kurun waktu dalam sejarah memberikan pula kondisi-kondisi kehidupan yang membentuk dan mempengaruhi kerangka pemikiran, (frame of refrence) dan medan pengalaman (field of experience) dengan muatan kepentingan yang berbeda, seehingga proses pemahaman terhadap suatu ketentuan Undang-undang Dasar dapat terus berkembang dalam praktik di kemudian hari. Oleh karena itu, penafsiran terhadap Undang-undang Dasar pada masa lalu, masa kini, dan pada masa yang akan datang, memerlukan rujukan standar yang dapat dipertanggungjawabkan dengan sebaik-baiknya, sehingga Undang-undang Dasar tidak menjadi alat kekuasaan yang ditentukan secara sepihak oleh pihak mana pun juga. Untuk itulah, menyertai penyusunan dan perumusan naskah Undang-undang Dasar, diperlukan pula adanya pokok-pokok pemikiran konseptual yang mendasari setiap perumusan pasal-pasal Undang-

\footnotetext{
11 Ibid.

12 Jimly Asshiddiqie, Konstitusi dan Konstitusionalisme Indonesia, (Jakarta: Sinar Grafika, 2014) hal,
} 29-30. 
Undang Dasar serta keterkaitanya secara langsung atau tidak langsung terhadap semangat Proklamasi Kemerdekaan 17 Agustus 1945 dan Pembukaan Undang-Undang Dasar. ${ }^{13}$

Mahkamah Kosntitusi dikatakan dalam pertimbangan Undang-undang Mahkamah Konstitusi maupun pasal 1 ayat (1) Undang-undang Mahkamah Konstitusi adalah salah satu pelaku kekuasaan kehakiman yang berfungsi menangani perkara tertentu di bidang ketatanegaraan dalam rangka menjaga konstitusi agar dilaksanakan secara bertanggung jawab sesuai dengan kehendak rakyat dan cita-cita demokrasi (Penjelasan UU MK). Pasal 24C ayat (1) UUD 1945 daan Pasal 10 Undang-undang Mahkamah Konstitusi menegaskan bahwa Mahkamah Konstitusi berwenang untuk mengadili dan memutus pada tingkat pertama dan terakhir yang putusanya bersifat final, perkara-perkara ketatanegaraan tertentu. Dalam menyelenggarakan peradilan yang demikian tentu saja Mahkamah Konstitusi harus mendasarkan pada ketentuan hukum acara, sebagaimana badan peradilan lain yang juga melaksanakan kekuasaan kehakiman. 14

Konsekuensi logis dari kenyataan bahwa tanpa konstitusi negara tidak mungkin terbentuk, maka konstitusi menempati posisi yang sangat krusial dalam kehidupan ketatanegaraan suatu negara, ibarat "Perjalanan cinta Romeo dan Juliet yang setia dan abadi" Demikian halnya negara dan konstitusi merupakan lembaga yang tidak dapat dipisahkan satu dengan yang lain. Dr. A. Hamid S. Attamimi, dalam disertasinya berpendapat tentang pentingnya suatu konstitusi atau Undang-undang Dasar adalah sebagai pemberi pegangan dan pemberi batas, sekaligus tentang bagaimana kekuasaan negara harus dijalankan. ${ }^{15}$

A.A.H. Struyken berpendapat bahwa Undang-undang Dasar sebagai konstitusi tertulis merupakan sebuah dokumen formal yang berisi: ${ }^{16}$

1. Hasil perjuangan politik bangsa di waktu yang lampau.

2. Tingkat-tingkat tertinggi perkembangan ketatanegaraan bangsa.

3. Pandangan tokoh-tokoh bangsa yang hendak diwujudkan baik untuk waktu sekarang maupun masa yang akan datang,

4. Suatu keinginan, dengan mana perkembangan kehidupan ketatanegaraan bangsa hendak dipimpin.

Jelas bahwa konstitusi Indonesia saat ini ialah Undang- undang Dasar 1945 sebagai dasar dan ideologi negara. Penjelasan umum UUD 1945 secara tegas menyatakan bahwa; "Undangundang Dasar suatu negara ialah hanya sebagian dari hukum dasar negara itu. Undang-undang

13 Ibid., hal 30.

14 Maruarar Siahaan, Hukum Acara Mahkamah Konstitusi Republik Indonesia (Jakarta: Sinar Grafika, 2012) hal, 1-2.

15 Dahlan Thaib, Jazim Hamidi dan Ni'matul Huda, Teori ..., op.cit., hal 56-57.

16 Dahlan Thaib, Jazim Hamidi dan Ni'matul Huda, Teori ..., op.cit., hal 81. 
Dasar ialah hukum dasaar yang tertulis, sedangkan di samping undang-undang itu berlaku juga hukum dasar yang tak tertulis, ialah aturan-aturan dasar yang timbul dan terpelihara dalam praktik penyelenggaraan negara, meskipun tidak tertulis....". ${ }^{17}$

Menggaris bawahi Penjelasan Umum UUD 1945 tersebut dapat disimpulkan bahwa kehidupan ketatanegaraan Republik Indonesia selain dilaksanakan berdasarkan kaidah-kaidah hukum tertulis (UUD), juga memerhatikan kaidah-kaidah hukum yang tak tertulis. Kaidahkaidah hukum yang tak tertulis itu tumbuh dan berkembang berdampingan secara paralel dengan kaidah-kaidah hukum yang tertulis. ${ }^{18}$

Penafsiran terhadap suatu konstitusi pada dasarnya dapat dilakukan oleh siapa saja atau lembaga mana saja. Akan tetapi, tidak dapat dibayangkan pertarungan sengit yang akan terjadi apabila terdapat pnafsiran yang berbeda-beda antara pihak atau lembaga yang satu dengan pihak atau lembaga yang lain. ${ }^{19}$

Gagasan mengenai konstitusi sebagai hukum dasar negara sebenarnya muncul bersamaan dengan munculnya kembali asas-asas demokrasi di Eropa yang mengangkat masalah hk-hak politik rakyat sebagai hak asasi manusia (HAM). Masalah tersebut menjadi tema dasar dalam pemikiran politik ketatanegaraan. Sehingga muncul pemikiran mengenai bagimana membatasi kekuasaan pemerintah melalui pembuatan Undang-undang Dasar yang kemudian disebut konstitusi. Di dalam konstitusi inilah bisa ditentukan batasan-batasan kewenangan dan kekuasaan pemerintah serta adanya jaminan akan hak-hak politik rakyat, sehingga kekuasaan pemerintah juga terimbangi dengan aspirasi rakyat yang terimplementasidala kekuasaan parlemen dan jaminan konstitusional dari lembaga-lembaga hukum. ${ }^{20}$

Pada awal pemberlakuanya, konstitusi sebagai hukum dasar (droit constitusional) negara masih bersifat formal. Artinya, konstitusi hanya memberikan pijakan formal bagi batasanbatasan kekuasaan pemerintah. Sehingga pemerintah lebih bersifat fasif, yaitu hanya menjadi wasit atau pelaksana dari berbagai keinginan rakyat yang dirumuskan di parlemen. Di sini peranan negara lebih kecil, tak ubahnya sebagai penjaga malam dari kebebasaan individualisme rakyat yang diperjuangkan melalui parlemen. Negara yang dulunya memiliki kekuasaan absolut, mulai terkikis dengan batasan-batasan kekuasaan yang konstitusional. Fenomena pemerintahan

17 Dahlan Thaib, Jazim Hamidi dan Ni'matul Huda, Teori dan Hukum Konstitusi (Jakarta: Rajagrafindo Persada, 2013) hal, 123.

${ }^{18}$ Dahlan Thaib, Jazim Hamidi dan Ni'matul Huda, Teori..., Loc Cit., hal, 123.

${ }_{19}$ Penafsiran Konstitusi dalam Pengujian Undang-undang Terhadap Undang-Undang Dasar, Pusat Penelitian, Pengkajian Perkara dan Pengelolaan Teknologi Informasi dan Komunikasi, 2016, hal, 13.

20 Soimin dan Mashuriyanto, Mahkamah Konstitusi dalam Sistem Ketatanegaraan Indonesia (Yogyakarta: UII Press, 2013) hal, 30. 
konstitusional di atas terjadi sekitar abad ke-19, sebagai fenomena munculnya kembali asas-asas demokrasi liberalisme. ${ }^{21}$

Keberadaan Mahkamah Konstitusi dalam penyempurnaan atau merevisi aturan-aturan yang telah dibuat menjadi problematika sendiri bagi MK apabila tidak tersampainya revisi tersebut kepada obyek tertentu. Memang salah satu kewenangan MK adalah untuk menguji dan membatalkan (to side aside) tindakan organ undang-undang apabila diyakini tidak konsisten dengan konstitusi. Tapi, fakta menunjukan bahwa putusan final dan mengikat MK sering tidak direspon positif oleh organ terebut. Bahkan, putusan final tidak jarang memperoleh tantangansengit dari segelintir aktor-aktor negara non-yudisial. Di beberapa negara, kondisi ini cenderung merepresentasikan krisis konstitusional. ${ }^{22}$

Besar kemungkinan putusan MK tidak implementaatif. Tidak diragukan lagi bahwa putusan MK selalu dihadang oleh kompleksitas permasalahan yang mengemuka di tahap aplikasi putusan final. Melihat kenyataan ini perlu ada strategi kesadaran kolektif yang melibatkan seluruh lembaga negara, aktor negara dan aktor non-negara sehingga strategi implementasi putusan final menuntut visi koordinatif antarlembaga negara agar problem implementasi dapat segera diatasi bersama. ${ }^{23}$

\section{Eksistensi Mahkamah Konstitusi dalam Revisi UU}

Keberadaan MK dalam merevisi sebuah Undang-undang atau Peraturan Pemerintah lainya merupakan kekuatan bagi masyarakat dalam melawan dan mencari keadilan terhadap peraturan. Mahkamah Konstitusi sudah puluhan kali menguji undang-undang yang megatur kewenanganya dan sudah puluhan kali pula putusan MK tersebut menimbulkan pro-kontra di tengah masyarakat, namun kajian ini hanya berkaitan dengan putusan yang dikabulkan oleh MK dan menyatakan batal sebuah pasal/ayat atau undang-undang secara keseluruhan. Artinya hasil temuan ini tidak termasuk putusan-putusan MK yang menolak perkara (putusan ditolak atau tidak diterima). Beberapa putusan MK yang mengundang pro-kontra di tengah masyarakat, antara lain putusan No. 066/PUU-II/2004,putusan No. 005/PUU-IV/2006, Putusan No. 138/PUU-VII/2009, Putusan MK No. 48/PUU-IX/2011,Putusan No. 49/PUU-IX/2011, dan Putusan No. 1-2/PUU-XII/2014. ${ }^{24}$

Untuk melihat pro-kontra "apakah MK boleh/tidak menguji undang-undang yang mengatur kewenanganya, tentu tidak cukup dengan pendapat MK saja, pendapat Komisi

${ }^{21}$ Ibid., hal, 30-31.

${ }^{22}$ Inosentius Samsul, Pengkajian Hukum Tentang Mahkamah Konstitusi, Badan Pembinaan Hukum Nasional Kementerian Hukum dan HAM RI, 2006, hal. 73.

${ }^{23}$ Inosentius Samsul, Pengkajian..., loc, cit.

24 Tanto Lailam, Pro-Kontra Kewenangan Mahkamah Konstitusi dalam Menguji Undang-Undang yang Mengatur Eksistensinya, Jurnal Konstitusi Vol 12, Nomor 4, 2015. 
Yudisial atau yang lainya, temasuk implikasi baik/buruknya sebuah putusan. Untuk itu diperlukan bangunan teori dengan mengelaborasi nilai-nilai filosofis, sosiologis, dan yuridis dalam tatanan sistem hukum Indonesia. Bangunan argumentasi pro-kontra tersebut cukup kuat, masing-masing memiliki argumentasai yang dapat dinalar dan dinilai benar oleh pihak tertentu, tetapi dalam konteks ini yang perlu dikonstruksikan adalah makna kebenaran dan keadilan menurut konstitusi. ${ }^{25}$

Kewenangan MK dalam menguji undang-undang yang mengatur eksistensinya harus dilakukan dengan hati-hati (prinsip kehati-hatian) dan pertanggungjawaban, kewenangan MK ini harus dilakukan oleh hakim-hakim yang benar-benar seorang negarawan yang adil, hakim yang mampu membaca secara komprehensif makna konstitusi sebagai the living constitution yang memiliki filosofi bahwa "konstitusi itu hidup" sehingga dalam menafsirkan konstitusi yang perlu diutamakan adalah perkembangan masyarakat saat ini. Selain itu, Hakim MK harus terseleksi moralitasnya, dan bebas dari kepentingan partai politik. Untuk mengantisipasi penyalahgunaan kewenangan melaalui putusan atau penafsiran yang keluar dari rel konstitusi, putusan yang kering makna kebenaran konstitusi, maka diperlukan pengawaasan dari segenap bangsa Indonesia mulai dari proses rekrutmen hakim konstitusi oleh DPR, Presiden, dan MA, dan pengawasan setiap putusan yang dikeluarkan. Pengawasan segenap bangsa Indonesia ini karena tidak adanya lembaga negara yang memberikan pengawasan terhadap hakim-hakim $\mathrm{MK}^{26}$

Suatu kenyataan bahwa pengesahan rancangan undang-undang menjadi undang-undang bukan merupakan sesuatu yang telah final. Undang-undang tersebut masih dapat dipersoalkan oleh masyarakat yang merasa hak konstitusionalnya dirugikan jika undang-undang itu jadi dilaksanakan, atau oleh segolongan masyarakat dinilai bahwa undang-undang itu bertentangan dengan norma hukum yang ada di atasnya, misalnya melanggar pasal-pasal UUD 1945. Kondisi demikian mengundang kegelisahan para pembentuk undang-undang. Betapa tidak, sebuah undang-undang yang telah disetujui oleh limaratusan anggota DPR plus pemerintah ternyata dapat dibatalkan Cuma oleh sembilan orang hakim konstitusi atau sedikitnya lima orang hakim. Secara kuantitas, undang-undang hanya dibentuk oleh sebagian rakyat melalui wakilnya di DPR bersama pemerintah, sementara UUD 1945 dibentuk oleh seluruh bangsa Indonesia yang terwakili dalam MPR. Artinya yng membentuk UUD lebih banyak jumlahnya daripada yang membentuk undang-undang. Berdasarkan UUD inilah Mahkamah Konstitusi diberikan otoritas atau kekuasaan untuk menjaga dan sekaligus menafsirkan konstitusi. Uiji undang-undang ini dapat berupa uji material dan uji formil. Uji material apabila yang dipersoalkan adalah muatan

25 Ibid.,

${ }^{26}$ Ibid., 
materi undang-undang yang bersangkutan, sedangkan uji formil apabila yang dipersoalkan adlah prosedur pengesahanya. ${ }^{27}$

Hakim Mahkamah Konstitusi dalam memutuskan suatu permohonan terhadap pengujian Undang-undang harus bersifat progresif sebagaimana dalam pandangan Satjipto Rahardjo yaitu putusan hakim yang mampu memenuhi kebutuhan bangsa dan putusan tersebut diputuskan karena merasakan dari penderitaan atau masalah yang dihadapi bangsanya sehingga melalui putusan tersebut masalah/penderitaan tersebut mapu terpecahkan. Artinya putusan MK ini merupakan putusan yang baik dan merupakan terobosan hukum yang pertama, bahwa MK tidak terkungkung pada teks (Pasal) yang tidak adil dan jelas-jelas menghambat jalanya MK dalam menegakkan hukum dan keadilan melalui pengujian undang-undang. ${ }^{28}$

Jika sebuah Perppu ingin dilakukan judicial review oleh MKRI maka layaknya jika Perppu sudah disetujui oleh DPR untuk menjadi UU dan diundangkan sebuah UU yang menyatakan Perppu tertentu menjadi sebuah UU. Perppu jika tidak disetujui oleh DPR dibentuk UU yang mengundangkan pencabutan Perppu. "Pembahasan rancangan Undang-undang tentang Pencabutan Peraturan Pemerintah Pengganti Undaang-undang dilaksanakan melalui mekanisme khusus yang dikecualikan dari mekanisme pembahasan Rancangan Undang-Undang." ${ }^{29}$

Mahkamah Konstitusi memahami UUD 1945 dalam kaitanya dengan uji materi secara ekstensi, artinya bukan hanya konstitusi yang tidak tertulis, dalam hal ini juga nilai-nilai ketatanegaraan beserta kebiasaan dan kesadaran hukum bangsa, semua ini telah menjadi bagian oleh majelis hakim dalam memutus perkara. Oleh karena hal itu, setidaknya terdapat tiga implikasi konkret Putusan Judicial Review oleh MK; ${ }^{30}$

1. Putusan-putusan yang bersifat ultra petita sudah akan menimbulkan kesan bahwa MK sudah bukan lagi merupakan negative legislator (penghapus/pembatal norma) melainkan positive legislator (pembuat norma). Di sisi lain hal ini dapat dinyatakan sebagai bagian dari penjagaan konstitusi atau bahkan wewenang diskresioner oleh MK, namun di pihak lain, dikhawatirkan hal ini akan memunculkan semacam "absolutism konstitusional" serta merugikan kepentingan hukum pihak pemohon (reformation in peius). Tetapi kiranya mekanisme dissenting opinion dan budaya transparansi yang menjadi hallmaark MK selama ini dapat menjadi couter balance atas kemungkinan-kemungkinan diatas, perlu juga

${ }_{27}$ Taufiqurrohman Syahuri, Tafsir Konstitusi Berbagai Aspek Hukum, (Jakarta, Prenadamedia Group, 2011) hal, 112.

28 Tanto Lailam, Pro-Kontra Kewenangan Mahkamah Konstitusi dalam Menguji Undang-Undang yang Mengatur Eksistensinya, Jurnal Konstitusi, Vol 12 Nomor 42015.

${ }^{29}$ Bolmer Suryadi Hutasoit, Eksistensi Mahakamah Konstitusi dalam Pengujian Praturan Pemerintah Pengganti Undang-Undang, (Skripsi, Fakultas Hukum Universitas Negeri Semarang, 2013) hal., 186.

30 Fista Prilia Sambuari, Eksistensi Putusan Judicial Review Oleh Mahkamah Konstitusi, Lex Admnistratum, Vol. 1 No. 2, 2013. 
ditambahkan disini bahwa acapkali putusan ultra petita adalah suatu yaang tak terelakkan, mengingat penghapusan suatu pasal langsung memiliki dampak sistemik, hingga perlu juga dihapuskanya bagian-bagian yang memiliki keterkaitan konseptual-normatif denganya.

2. Putusan-putusan MK memainkan peranan vital bagi pembentukan hukum nasional dalam kerangka negara hukum (rechtstaat), pertama bagi pihak legislatve, putusan MK dapat mengukuhkan sifat konstitusional suatu UU yang berdampak positif bagi penguatan tertib hukum nasional, kedua meningkatkan kehati-hatian lembaga legislatif dalam membuat undang-undang, dalam hal ini agar jangan saampai terlalu banyak bermuat kepentingan politis namun dimensi konstitusionalnya lah yang ditekankan; khususnya pendekatan heuristic yang mengakomodasi perkembangan segi-segi social-psikologis masyarakat.

3. Putusan-putusan MK mencerminkan perkembangan teori hukum di Indonesia, selama ini konon ilmu hukum tata negara di Indonesia hanya merupakan catatan kaki dari pikiranpikiran kelsen dan nawaisky; namun Pasal 2 UU No. 24 Tahun 2003 menyatakan bahwa kedudukan MK adalah guna menyelenggarakan peradilan guna menegakkan "hukum dan keadilan", "hukum" adalah istilah yuridis, sedangkan "keadilan" adalah istilah etis-sosiologis, dari sini dapat diraba bahwa pencarian "hukum substantif" tak lain adalah rangkaian diskusi panjang yang produktif antara positivisme dan sosiologi hukum, dan secara historis dialektika antara kedua elemen konstitutif dalam masyarakat tidak ditemukan dalam pikiraan-pikiran Kelsen dan Nawiasky, melainkan pada tulisan kolega Kalsen yakni Herman Heller (18911933).

Mahkamah konstitusi dalam pelaksanaan kewenangan dalam menguji undang-undang beserta kewajibanya dan juga tanggung jawabnya dalam memutuskan pada saat judicial review memiliki peraturan dalam pelaksanaanya sebagaimana yang tertera dalam Undang-Undang Republik Indonesia Nomor 8 Tahun 2011 Tentang Perubahan Atas Undang-undang Nomor 24 Tahun 2003 Tentang Mahkamah Konstitusi Pasal 50A berbunyi; "Mahkamah Konstitusi dalam mwnguji undang-undang terhadap Undang-undang Dasar Negara Republik Indonesia Tahun 1945 tidak menggunakan undang-undang lain sebagai dasar pertimbangan hukum". Dan juga dalam setiap putusaanya tidak boleh bertentangan dengan dasar atau falsafah negara seperti bunyi dalam Pasal 57 poin (1); "Putusan Mahkamah Konstitusi yang amar putusanya menyatakan bahwa materi muatan ayat, pasal, dan/atau bagian undang-undang bertentangan dengan Undang-undang Dasar Negara Republik Indonesia Tahun 1945, materi muatan ayat, pasal, dan/atau bagian undang-undang tersebut tidak mempunyai kekuatan hukum mengikat". ${ }^{1}$

\section{Mahkamah Konstitusi dalam Pelaksanaan Judicial Review}

31 Undang-Undang Republik Indonesia Nomor 8 Tahun 2011 Tentang Perubahan Atas Undangundang Nomor 24 Tahun 2003 Tentang Mahkamah Konstitusi. 
Indonesia adalah negara hukum yang memiliki aturan lama dan baru yang memiliki manfaat masing-masing dalam penataan negara menuju yang lebih baik. Aturan Undang-undang terkadang dibuat tidak sesuai oleh pemerintah sehingga peranan MK dalam merevisi atau Judicial Review berdasarkan permohonan dari pihak yang tidak menerimanya. "Judicial Review" (hak uji materil) merupakn kewenangan lembaga peradilan untuk menguji kesahihan dan daya laku produk-produk hukum yang dihasilkan oleh eksekutif legislatif maupun yudikatif di hadapan konstitusi yang berlaku. Pengujian oleh hakim terhadap produk cabang kekuasaan legislatif (legislative acts) dan cabang kekuasaan eksekutif (executive acts) adalah konsekuensi dari dianutnya prinsip 'checks and balances' berdasarkan doktrin pemisahan kekuasaan (separation of power). Karena itu kewenangan untuk melakukan 'judicial review' itu melekat pada fungsi hakim sebagai subjeknya, bukan pad pejabat lain. Jika pengujian tidak dilakukan oleh hakim, tetapi oleh lembaga parlemen, maka pengujian seperti itu tidak dapat disebut sebagai 'judicial review' melainkan legislative review. ${ }^{32}$

Istilah Judicial Review berkembang pesat di Amerika Serikat dan beberapa negara Eropa Barat lainya pada akhir abad ke-17 dan awal abad ke-18. Ratusan buku, artikel, esai, pernyataan, manifesto, dan pendapat peradilan bergumul dengan masalah-masalah hak uji materil (judicial review), dan bagaimana membenarkan hak uji material dalam masyarakat yang demokratis. Dalam diskursus tersebut muncul suatu pendirian teguh bahwa penegak hukum (Mahkamah Agung) harus mampu memberikan makna pada sistem tata negara, khususnya menegakkan hakhak minoritas. Maka iti dari diskursus tersebut adalah untuk mencegah "tirani konstitusional" baik minoritas oleh mayoritas ataupun mayoritas oleh minoritas. ${ }^{33}$

Kewenangan MK dalam sistem hukum Indonesia adalah menguji konstitusionalitas norma undang-undang terhadap UUD 1945. Kewenangan MK dalam melakukan pengujian undng-undang lahir dalam sistem hukum indonesia pasca amandemen ke-III UUD 1945. Hal ini dilatarbelakangi oleh kenyataan bahwa dalam sistem hukum indonesia sebelum amandemen ketiga, tidak dikenal mekanisme dalam menjamin konsistensi antara undaang-undang dan UUD 1945. Selama ini mekanisme pengujian yang dikenal adalah mekanisme judicial review yang dilakukan oleh Mahkamah Agung. Judicial Review yang dilakukan oleh oleh Mahkamah Agung hanya meliputi pengujian terhadap peraturan di bawah undang-undang antara lain peraturan pemerintah, PerPPU, Kepres dll. ${ }^{34}$

32 Inosentius Samsul, Pengkajian Hukum Tentang Mahkamah Konstitusi, Badan Pembinaan Hukum Nasional Kementerian Hukum dan HAM RI, 2006, hal. 43.

33 Soimin dan Mashuriyanto, Mahkamah Konstitusi dalam Sistem Ketatanegaraan Indonesia (Yogyakarta: UII Press, 2013) hal, 123.

34 Widati Wulandari dkk, Kewenangan Mahkamah Konstitusi dalam Melakukan Judicial Review Terhadap Undang-Undang Pidana yang Mengakbatkan Perubahan Norma dalam Hukum Pidana Materil 
Konstitusi Indonesia dalam merevisi atau mereview Undang-undang terhadap UndangUndang Dasar 1945 sesuai dengan gagasan modern tentang sistem pemerintahan demokratis yang didasarkan pada prinsip pemisahan kekuasaan dan perlindungan hak asasi manusia (the protector of humn rights). Hal ini didasarkan pada tujuan dibentuknya MK, yakni sebagai upaya menegakkan hak-hak dasar warga negara yang sesuai dengan prinsip-prinsip HAM di dalam konstitusi dan juga merupakan ciri dari negara hukum. Tugas pokok dari konstitusional review adalah: ${ }^{35}$

1. Menjamin berfungsinya sistem demokrasi dalam hubungan peran atau interplay antara cabang kekuasaan eksekutif, legislatif dan yudikatif. Dengan adanya konstitusional review. Maka dominasi kekuasaan dan/atau penyalahgunaan kekuasaan oleh salah satu cabang kekuasaan dapat dicegah.

2. Melindungi setiap individu warga negara dari penyalahgunaan kekuasaan oleh lembaga Negara yang merugikan hak-hak fundamental mereka yang dijamin di dalam konstitusi.

Pembagian dua jenis Judicial Review menurut Jimly Asshiddiqie, yaitu concrete norm review dan abstact norm review: ${ }^{36}$

1. Concrete norm review tersebut dapat berupa;

a. Pengujian terhadap norma konkrit terhadap keputusan-keputusanyang bersifat administrative (beschiking), seperti dalam PTUN (Peradilan Tata Usaha Negara),

b. Pengujian terhadap norma konkrit dalam jenjang peradilan umum, seperti pengujian putusan peradilan tingkat pertama oleh peradilan banding, pengujian putusan peradilan kasasi oleh Mahkamah Agung.

2. Abstract norm review yaitu kewenangan pengujian produk perundang-undang yang menjadi tugas dari MK-RI yang diinspirasi dari putusan John Marshall dalam kasus Marbury Vs. Madison di Amerika. Sebagian dari kewenangan abstract norm review ini masih diserahkan kepada MA-RI berupa kewenangan pengujian produk perundang-undangan di bawah undangundang.

Hans Kelsen, salah seorang ilmuwan hukum yang berpengaruh pada abad XX diminta untuk merancang konstitusi Republik Austria, sebagai negara baru yang lahir dari runtuhnya kekaisaran Austro Hungarian tahun 1919. Ada dua konsep dasar pemikiran Hans Kelsen yang berkenaan dengan diperlakukanya dibentuk suatu badan kenegaraan yang mempunyai kewenangan pengujian atau Judicial Review, sebagai berikut: ${ }^{37}$

Ditinjau dari Asas Legalitas, Pusat Penelitian dan Pengkajian Perkara, dan Pengelolaan Perpustakaan Kepaniteraan dan Sekretariat Jenderal Mahkamah Konstitusi, 2019, hal 10.

35 Ibid., hal 12.

${ }^{36}$ Pusat Studi Konstitusi FH Andalas, Perkembangan..., op, cit. 2012).

${ }^{37}$ Nurul Qomar, Kewenangan Judicial Review Mahkamah Konstitusi, (Jurnal Konstitusi, Vol 1 No 1 
1. Konstitusi harus didudukan sebagai norma hukum yang superior dari undang-undang biasa dan harus ditegakan menurut superioritasnya.

2. Adanya ketidak percayaan luas terhadap badan peradilan biasa dalam melaksanakan penegakan konstitusi, sehingga diperlukan suatu badan khusus yang terpisah dari pengadilan biasa untuk mengawasi undang-undang serta membatalkanya jika ternyata bertentangan dengan UUD sebagai perangkat norma hukum dasar bernegara.

Mahkamah Konstitusi dalam pengujian Undang-undang terhadap UUD 1945 memiliki aturan sebagai dasar hak dan kewajibanya dalam bertindak. UURI No. 24 Tahun 2003 Tentang Mahkamah Konstitusi Pasal 10 Poin 1: Mahkamah Konstitusi berwenang mengadili pada tingkat pertama dan terakhir yang putusanya bersifat final untuk: a. Menguji undang-undang terhadaap Undang-undang Dasar Negara Republik Indonesia Tahun 1945. ${ }^{38}$

Asas-asas hukum publik menjadi landasan dalam proses beracara judicial review. Merujuk pada jenisnya, hukum acara Judicial Review terdiri dari hukum acara sengketa (contentious procesrecht) dalam bentuk gugatan dan hukum acara non sengketa (non-contentious procesrecht) dalam bentuk permohonan tanpa ada dua pihak yang bersengketa. Asas-asas hukum publik yang menjadi landasan adalah judicial review antara lain asas Praduga Rechmatig; putusan MK memiliki kekuatan mengikat dan harus ditaati tidak hanya oleh pihak yang berperkara (erga omnes); asas res judicata pro veritate habetur; asas para pihak harus didengar; asas peradilan cepat, sederhana dan biaya ringan: asas curia novit; dan asas dominis litis. $^{39}$

Konstitusi di Indonesia sudah dikatakan baik dalam penyempurnaan undang-undang pada saat pemberian putusan terhadap pelaksanan Judicial Review .Putusan MK merupakan putusan akhir dan mempunyai akhir dan mempunyai kekuatan hukum tetap pada saat putusan dibacakan. Suatu objek produk hukum yang diajukan judicial review dianggap sah sampai terdapat putusan Hakim atau Hakim MK yang membatalkanya (en nunc). Sedangkan asas putusan memiliki kekuatan mengikat (erga omnes) yakni berlandas pada sifat hukum publik, sehingga putusan pada perkara judicial review haruslah merupakan putusan yang mengikat bagi para pihak dan harus ditaati oleh siapapun. ${ }^{40}$

\section{E. MK dan MA dalam menguji UU atau Peraturan Pemerintah}

38 Undang-Undang Komisi Yudisial dan Mahkamah Konstitusi, (Bandung: Fokusmedia, 2012) hal, 6566.

39 Widati Wulandari dkk, Kewenangan Mahkamah Konstitusi dalam Melakukan Judicial Review Terhadap Undang-Undang Pidana yang Mengakibatkan Perubahan Norma dalam Hukum Pidana Materil Ditinjau dari Asas Legalitas, Pusat Penelitian dan Pengkajian Perkara, dan Pengelolaan Perpustakaan Kepaniteraan dan Sekretariat Jenderal Mahkamah Konstitusi, 2019, hal 13.

40 Ibid., hal. 13-14. 
Mahkamah Konstitusi dan Mahkamah Agung merupakan suatu lembaga pemerintah yang menguji UU namun berbeda dasar dan kewenangan yang tertuang di undang-undag tersendiri. MA dan MK sama-sama memiliki kewenangan judicial review, namun objeknya berbeda. MA berwenang menguji peraturan perundang-undangan di bawah undang-undang terhadap undangundang, sementara MK berwenang menguji undang-undang terhadap UUDNRI Tahun 1945. Melihat kewenangan judicial review yang dimiliki oleh MA dan MK tersebut, tentu secara tidak langsung memberikan gambaran bahwa MK memiliki kedudukan lebih tinggi dari pada MA, sementara menurut ketentuan yang terdapat di dalam UUDNRI Tahun 1945, MA dan MK itu memiliki kedudukan yang sama dalam sistem ketatanegaraan Indonesia. Hal itu terlihat dari objek yang diuji, terdapat pembatasan produk hukum yang akan diuji oleh MA, yang secara langsung membatasi MA untuk melakukan kontrol secara normatif terhadap setiap produk hukum. MA hanya berwenang mengadili peraturan perundang-undangan dibawah undangundang terhadap undang-undang, sementara untuk peraturaan yang lebih tinggi, yaitu undangundang terhadap UUDNRI Tahun 1945 kewenanganya dimiliki oleh MK. Tentu hal ini dapat menimbulkan persoalan hukum. ${ }^{41}$

Pemberian kewenangan pada substansi yang sama, yakni pengujian peraturan perundangundangan, tetapi membedakan objeknya dengan organisasi yang berbeda tetapi dalam kelembagaan negara yang sama, yakni kekuasaan kehakiman, dikemudian hari akan menimbulkan berbagai kerancuan normatif dan kerancuan teknis. Pemisahan kewenangan pengujian peraturan perundang-undangan antara Mahkamah Agung dan Mahkamah Konstitusi sebagaimana diatur dalam Pasal 24A ayat (1) dan Pasal 24C ayat (1) UUD 1945 tidaklah ideal karena dapat menimbulkan problem hukum yang rumit. Sri soemantri menegaskan, ada kaitan antara Undang-undang dan peraturan dibawahnya. Berdasarkan ketentuan yang ada jika PP, Perpres, Perda bertentangan dengan Undang-undang maka akan diuji oleh MA. Problematika yang muncul adalah, jika Undang-undang yang digunakan untuk menguji sedang diuji di MK dan ternyata diputuskan bahwa Undang-Undang dimaksud bertentangan dengan UUDNRI Tahun 1945, maka menjadi tidak relevan permohonan untuk menguji PP, karena UU yang dijadikan hukum pembuatan PP tidak dapat lagi berlaku. ${ }^{42}$

Menurut Jimly, ada empat alasan yang menyebabkan dualisme pengujian peraturan tersebut menjadi tidak ideal, yaitu sebagai berikut: ${ }^{43}$

1. Pemberian kewenangan pengujian (Judicial Review) materi undang-undang terhadap Undangundang dasar kepada MK yang baru dibentuk megesankan hanya sebagian tambahan

${ }^{41}$ Antoni Putra, Dualisme Pegujian Peraturan Perundang-Undangan, Jurnal Legislasi Indonesia Vol, 15 No, 2, 2018.

42 Ibid,.

${ }^{43}$ Antoni Putra, Dualisme.... op, cit. 
perumusan terhadap materi UUDNRI Tahun 1945 secara mudah dan tambah sulam, seakanakan konsepsi hak uji materil peraturan yang ada di tangan MA tidak turut berpengaruh dengan hak uji yang diberikan kepada MK. Perumusan demikian terkesan seakan kurang didasarkan atas pendalaman konseptual berkenaan dengan konsepsi uji materi itu sendiri scara komprehensif.

2. Pemisahan kewenangan itu masuk akal untuk dilakukan jika sistem kekuasaan yang dianut masih didasarkan atas prinsip pembagian kekuasaan sebagimana yang dianut oleh UUDNRI Tahun 1945 sebelum mengalami perubahan pertama dan kedua, UUDNRI Tahun 1945 setelah perubahan pertama dan kedua, UUDNRI Tahun 1945 setelah perubahan telah resmi dan tegas menganut prinsip pemisahan kekuasaan horizontal mengutamakan prinsip checks and baalances. Oleh karena itu, pemisahan antara materi undang-undang dan materi peraturan di bawah undang-undang tidak seharusnya dilakukan lagi.

3. Dalam praktik pelaksanaanya nanti, secara hipotesis dapat timbul pertentangan substantif antara putusan MA dengan putusan MK. Oleh karena itu, sebaiknya sistem pengujian peraturan perundang-undangan di bawah konstitusi diintegrasikan saja di bawah MK. Dengan demikian masing-masing Mahkamah dapat memfokuskan perhatian pada masalah yang berbeda. MA menangani persoalan keadilan dan ketidakadilan bagi warga negara, sedangkan MK menjamin konstitusionlitas keselutuhan peraturan perundang-undangan.

4. Jika kewenangan pengujian materi peraturan di bawah UUDNRI Tahun 1945 sepenuhnya diberikan kepada MK, tentu beban MA dapat dikurangi.

Kemampuan dan kewenangan MA dalam menguji UU terhadap UU seperti yang dilaksanakan oleh MK dasar fungsi Hak Uji Materil (HUM) ditentukan dalam pasal 26 UU No. 14 Tahun 1970, tentang Pokok-Pokok Kekuasaan Kehakiman jo. Pasal 31 UU No. 14 Tahun $1985 .^{44}$

1. Mahkamah Agung berwenang untuk mengatakan tidak sah semua peraturan per undangundangan dari tingkat yang lebih rendah dari UU atas alasan bertentangan dengan peraturan perundaang-undangan yang lebih tinggi.

2. Putusan tentang pernyataan tidak sahnya peraturan perundang-undangan dapat diambil berhubungan dengan pemeriksaan dalam tingkat kasasi.

Pencabutan perundang-undangan yang dinyatakan tidak sah tersebut, dilakukan oleh instansi yang bersangkutan. Ketentuan Pasal 31 UU MA adalah sama isinya dengan ketentuan Pasal 26 UU 14 Tahun $1970 .{ }^{45}$

${ }^{44}$ UU No. 14 Tahun 1970, tentang Pokok-Pokok Kekuasaan Kehakiman jo. Pasal 31 UU No. 14 Tahun 1985.

${ }^{45}$ Henry P. Panggabean, Fungsi Mahkamah Agung, (Jakarta: Pustaka Sinar Harapan, Anggota IKAPI, 2001) hal, 127. 
Secara teoritis tidak terdapat hubungan diantara kedua lembaga pelaksana kekuasaan kehakiman itu. Tidak ditemukanya hubungan diantara kedua lembaga pelaksana kekuasaan kehakiman itu dalam hal kewenangan judicial review adalah dikarenakan objek yang menjadi kewenangan judicial review antara MA dan MK tidaklah sama. Sehingga sepintas, kondisi ini menunjukan tidak adanya hubungan dia antara kedua lembaga pemegang kewenangan judicial review itu. Namun demikian harus dipahami bahwa seluruh objek judicial review yang menjadi ranah kewenangan kedua lembaga dimaksud berada dalam satu jenjang hierarki peraturan perundang-undangan. Jenjang hierarki dimaksud mewajibkan seluruh peraturan perundangundangan yang tingkatanya lebih rendah untuk tunduk dan mempunyai peraturan hukum dari peraturan tingkat atasnya. ${ }^{46}$

Setidaknya ada 2 (dua) alasan untuk mengatakan bahwa model kewenangan judicial review sebagimana dianut bangsa Indonesia saat ini berpotensi menimbulkan permasalahan hukum, bahkan peluang rusaknya pilar-pilar hukum atas model kewenangan judicial review ini sangat sudah terbuka lebar. Pengalaman pahit itu setidaknya sudah pernah menimpa dunia peradilan di tanah air; ${ }^{47}$

1. Kewenangan judicial review yang melekat pada MK ternyata justru berpeluang untuk mematahkan atau menggugurkan putusan-putusan perkara judicial review terhadap suatu peraturan perundang-undangan yang saling berkaitan, terlebih dahulu dilakukan di MK, baru kemudian muncul perkara judicial review terhadap peraturan di bawahnya yang merupakan kewenangan MA, maka konsep kewenangan sebagaimana yang berlaku di Indonesia tidak akan menimbulkan persoalan. Hal ini dikarenakan adanya kewajiban bagi MA untuk menghentikan pengujian peraturan perundang-undangan di bawah undang-undang apabila undang-undang yaang menjadi dasar pengujian peraturan tersebut sedang dalam proses pengujian di MK sampai adanya putusan MK.

2. Penyerahan kewenangan judicial review kepada MA dan MK juga akan menyisakan kerumitan lain dalam hal perkara judicial review yang tidak bertentangan secara langsung terhadap peraturan setingkat di atasnya, namun bertentangan dengan peraturan yang lebih tinggi dengan peraturan di tingkat atasnya. Konkritnya, bila suatu Peraturan Daerah (Perda) atau Peraturan Pemerintah (PP) tidak bertentangan dengan Undang-undang, namun justru bertentangan langsung dengan UUD NRI Tahun 1945, lalu lembaga manakah yang memiliki kompetensi untuk melakukan judicial review terhadap persoalan semacam ini ?. kalau persoalan yang demikian diajukan ke MA, maka sesuai dengan kewenanganya bahwa batu uji yang digunakan adalah undang-undang. Sementara peraturan yang hendak diuji justru tidak

46 Janpatar Simamora, Analisaa Yuridis Terhadap Model Kewenangan Judicial Review di Indonesia, Mimbar Hukum Vol, 25, No 32013.

${ }^{47} \mathrm{Ibid}$. 
bertentangan dengan Undang-undang terkait. Dengan demikian, maka dapat dipastikan bahwa MA tidak akan mengabulkan permohonan judicial review dimaksud. Kalaupun kemudian diajukan ke MA dan kemudian MA menerimanya dengan megambil batu uji undang-undang sebagai peraturan tingkat atasnya, maka dapat dipastikan bahwa MA akan memberikan putusan dengan memberikan pertimbangan sesuai dengan ketentuan Undang-Undang terkait. Padahal sejak awal sudah jelas bahwa perkara yang hendak dilakukan upaya judicial review justru tidak bertentangan dengan Undang-undang, namun bertentangan dengan UUD NRI Tahun 1945. Sementara bila diajukan ke MK, maka dapat dipastikan bahwa lembaga pengawal konstitusi itu juga tidak akan menerima permohonan dimaksud mengingat persoalan yang diajukan bukan merupakan bagian dari kompetensi MK. Karena MK hanya berwenang menguji peraturan perundang-undangan yang bernama undang-undang terhadap UUD NRI Tahun 1945. Dalam situasi yang demikian, tentunya yang paling dirugikan adalah masyarakat luas khususnya para pencari keadilan, karena tidak tersedia sarana untuk melakukan judicial review dengan gambaran kasus sebagaimana diutamakan di atas. Artinya bahwa konsep kewenangan judicial review sebagaimana yang dijalankan saat ini di Indonesia semakin menunjukan titik lemahnya.

Jelaslah bahwa kewenangan antara dua lembaga yaitu Mahkamah Konstitus (MK) dan Mahkamah Agung (MA) dalam melaksanakan kewenangan Judicial Review berbeda baik itu berdasarkan teori kegunaan dan kegiatan lainya. Kewajiban dan tanggung jawab lembaga menjadi prioritas utama. Keduanya diberikan kewenangan yang berbeda oleh konstitusi. Pasal 24A UUD 1945 mengatur mengenai kewenangan MA dan Pasal 24C UUD 1945 untuk kewenangan MK. UUD 1945 menempatkan dua fungsi kekuasaan kehakiman kepada dua lembaga (MA dan MK) secara terpisah. Padahal, dari sudut pandang teoritis, kehadiran MK diidealkan sebagai mahkamah sistem hukum (court of law), sedangkan MA tetap dengan kedudukanya sebagai mahkamah keadilan (court of justice).

\section{Kesimpulan}

Keberadaan Mahkamah Konstitusi di Indonesia memiliki hak dan kewajiban, wewenang, tanggung jawab, dan juga peraturan yang mengikat yang membuat keberadaanya sebagai lembaga yang mengatur arah baru Undang-undang atau merevisi aturan-aturan pemerintah yang tidak sesuai dengan keinginan dan keberadaan masyarakat. MA dan MK dalam melakukan judicial review pun dalam teori dasar antar kedua lembaga tersebut berbeda dalam melakukan judicial review. Keduanya diberikan kewenangan yang berbeda oleh konstitusi. Pasal 24A UUD 1945 mengatur mengenai kewenangan MA dan Pasal 24C UUD 1945 untuk kewenangan MK. UUD 1945 menempatkan dua fungsi kekuasaan kehakiman kepada dua lembaga (MA dan MK) secara terpisah. 
Indonesia adalah negara hukum yang memiliki aturan lama dan baru yang memiliki manfaat masing-masing dalam penataan negara menuju yang lebih baik. Aturan Undang-undang terkadang dibuat tidak sesuai oleh pemerintah sehingga peranan MK dalam merevisi atau Judicial Review berdasarkan permohonan dari pihak yang tidak menerimanya. "Judicial Review" (hak uji materil) merupakan kewenangan lembaga peradilan untuk menguji kesahihandan daya laku produk-produk hukum yang dihasilkan oleh eksekutif legislatif maupun yudikatif di hadapan konstitusi yang berlaku. Eksistensi Mahkamah Konstitusi dalam mengatur undangundang berjalan dengan baik, namun sampai saat ini mahkamah konsitusi belum pernah membubarkan partai politik dan memberhentikan Presiden berdasarkan kewenanganya sebagai lembaga.

\section{DAFTAR PUSTAKA}

Aminuddin Ilmar, Hukum Tata Pemerintahan, (Jakarta: Prenadamedia Group, 2014).

Antoni Putra, Dualisme Pegujian Peraturan Perundang-Undangan, Jurnal Legislasi Indonesia Vol, 15 No, 2, 2018.

Bolmer Suryadi Hutasoit, Eksistensi Mahakamah Konstitusi dalam Pengujian Praturan Pemerintah Pengganti Undang-Undang, (Skripsi, Fakultas Hukum Universitas Negeri Semarang, 2013).

Dahlan Thaib, Jazim Hamidi dan Ni'matul Huda, Teori dan Hukum Konstitusi (Jakarta: Rajagrafindo Persada, 2010).

Dahlan Thaib, Jazim Hamidi dan Ni'matul Huda, Teori dan Hukum Konstitusi (Jakarta: Rajagrafindo Persada, 2013).

Encik Muhammad Fauzan, Hukum Tata Negara Indonesia, (Malang: Setara Press, 2017).

Fista Prilia Sambuari, Eksistensi Putusan Judicial Review Oleh Mahkamah Konstitusi, Lex Admnistratum, Vol. 1 No. 2, 2013.

Henry P. Panggabean, Fungsi Mahkamah Agung, (Jakarta: Pustaka Sinar Harpan, Anggota IKAPI, 2001).

Inosentius Samsul, Pengkajian Hukum Tentang Mahkamah Konstitusi, Badan Pembinaan Hukum Nasional Kementerian Hukum dan HAM RI, 2006. 
Janpatar Simamora, Analisa Yuridis Terhadap Model Kewenangan Judicial Review di Indonesia, Mimbar Hukum Vol, 25, No 32013.

Jimly Asshiddiqie, Model-model Pengujian Konstitusional di Berbagai Negara, (Jakarta: Konstitusi Press, 2006).

Jimly Asshiddiqie, Konstitusi dan Konstitusionalisme Indonesia, (Jakarta: Sinar Grafika, 2014).

M. Agus Santoso, Perkembangan Konstitusi di Indonesia, (Yustisia Vol 2 No 3 2013).

Mahkamah Konstitusi Republik Indonesia, Konsistensi Pada Konstitusi dan Ideologi Negara (Jakarta: Kepaniteraan dan Sekretariat Jenderal Mahkamah Konstitusi, 2018).

Maruarar Siahaan, Hukum Acara Mahkamah Konstitusi Republik Indonesia (Jakarta: Sinar Grafika, 2012).

Nurul Qomar, Kewenangan Judicial Review Mahkamah Konstitusi, (Jurnal Konstitusi, Vol 1 No $12012)$.

Penafsiran Konstitusi dalam Pengujian Undang-undang Terhadap Undang-Undang Dasar, Pusat Penelitian, Pengkajian Perkara dan Pengelolaan Teknologi Informasi dan Komunikasi, 2016.

Perkembangan Pengujian Perundang-Undangan di Mahkamah Konstitusi, Pusat Studi Konstitusi FH Andalas, Jurnal Konstitusi Vol, 7 No, 62010.

Pusat Studi Konstitusi FH Andalas, Perkembangan Pengujian Perundang-undangan di Mahkamah Konstitusi, Jurnal Konstitusi, Vol 7 No. 62010.

Soimin dan Mashuriyanto, Mahkamah Konstitusi dalam Sistem Ketatanegaraan Indonesia (Yogyakarta: UII Press, 2013).

Tanto Lailam, Pro-Kontra Kewenangan Mahkamah Konstitusi dalam Menguji Undang-Undang yang Mengatur Eksistensinya, Jurnal Konstitusi Vol 12, Nomor 4, 2015.

Taufiqurrohman Syahuri, Tafsir Konstitusi Berbagai Aspek Hukum, (Jakarta, Prenadamedia Group, 2011).

Undang-Undang Komisi Yudisial dan Mahkamah Konstitusi, (Bandung: Fokusmedia, 2012). 
Undang-Undang No. 14 Tahun 1970, tentang Pokok-Pokok Kekuasaan Kehakiman jo. Pasal 31 UU No. 14 Tahun 1985.

Undang-Undang Republik Indonesia Nomor 8 Tahun 2011 Tentang Perubahan Atas Undangundang Nomor 24 Tahun 2003 Tentang Mahkamah Konstitusi.

Widati Wulandari dkk, Kewenangan Mahkamah Konstitusi dalam Melakukan Judicial Review Terhadap Undang-Undang Pidana yang Mengakbatkan Perubahan Norma dalam Hukum Pidana Materil Ditinjau dari Asas Legalitas, Pusat Penelitian dan Pengkajian Perkara, dan Pengelolaan Perpustakaan Kepaniteraan dan Sekretariat Jenderal Mahkamah Konstitusi, 2019. 